\title{
I Hugo Matthiessens spor
}

\section{af Kim Furdal}

Begrebet "Hærvejen« er velkendt, men i virkeligheden noget misvisende. Oprindelig havde ordet en anden betydning end i dag. Den gamle hovedvej gennem Jylland var heller ikke én bestemt vej, men et bælte af varierende vejforlab.

Arkivar Kim Furdal fortæller her om de skiftende opfattelser af vejens forløb og funktion - og han påviser, hvordan fredningsbestræbelserne har ændret sig i takt med udviklingen $\mathrm{i}$ befolkningens ferie- og fritidsvaner. Artiklen skal ses i sammenhæng med den følgende om »Rechte Herr Weg«.

Hærvejen er ikke uden appeal. Da jeg for et stykke tid siden forespurgte en københavnsk antikvarboghandler om bøger vedrørende Hærvejen sukkede han, og svarede "Ak ja, den Hærvej, den Hærvej!«. Det var tydeligvis ikke første gang, han havde fået denne bestilling. Hærvejen er aktuel og måske mere nu end nogen sinde. Den folkelige interesse er ikke uden grund.

For den naturinteresserede løber den igennem en række af Jyllands mest karakteristiske og skønneste områder lige fra Alheden ved Viborg over Det store Vandskel ved Gudenåen og Skjernåens udspring til det bakkede og frodige morænelandskab ved Haderslev. For den historisk og kulturhistorisk interesserede skærer Hærvejen sig igennem Danmarkshistorie og dansk kulturhistorie med sine punktvise nedslag $\mathrm{i}$ landskabet som perler på en snor. Oldtidens gravhøje, middelalderens kirker og studedriverkroer for blot at nævne nogle få. Der er dramatiske højdepunkter lige fra slaget på Grathe Hede i 1157, slaget ved Bov den 9. april 1848 og clearingmordet på Kaj Munk den 4. januar 1944. Ikke alt er vold og dramatik. Mens kong Svend flygtede fra Grathe hede, fortsatte dagliglivet for den jyske bonde. Hærvejen er på samme tid historien om studeopdræt og studehandelen i Danmark fra slutningen af middelalderen op til det 19. århundrede.

\section{Den grønne bølge, danmarkshistorien og turismen}

Hærvejen samler trådene for en voksende interesse for dansk historie og kulturhistorie med en stigende interesse for natur og miljø. Samtidig lægger danskerne i stigende grad deres ferie i Danmark. Turistkontorerne kunne i 1990 begejstret melde om rekordagtige besøgstal langs Hærvejen. „God sæson ved Hærvejen« forlyder det i Vejle Amts Folkeblad den 16. august 1990, hvor 
indehaveren af Tøsby Kro kan berette om et langt bedre år end 1989, der heller ikke var noget dårligt år. Ganske typisk beretter kroejeren om et skift i danskernes turistvalg. Folk er blevet træt af charterrejser til syden, men ønsker aktiv ferie i Danmark med kulturelle ferietilbud.

Det er i tråd med denne udvikling, at der i 1974 blev nedsat en gruppe bestående af folk fra fredningsstyrelsen, Danmarks Naturfredningsforening, samt de berørte amter og museer med henblik på en koordineret planlægning for Hærvejen, "såvel ud fra kulturhistoriske som rekreative begrundelser«. Et af målene var bl.a. at skabe en sammenhængende vejføring for Hærvejen. Hærvejsgruppens arbejde mundede ud i to rapporter, der dels opsummerede den eksisterende viden om Hærvejen, dels vurderede Hærvejens og dens mange kulturmonumenters aktuelle tilstand. I sin vurdering af den eksisterende fredning af Hærvejen konkluderede udvalget, at "Der har kun i meget begrænset omfang været taget hensyn til de rekreative synspunkter, og den eksisterende hærvejsturisme er stort set ladt i stikken «. ${ }^{1}$ For at råde bod på dette forhold anbefalede gruppen, at der blev foretaget en gennemgang og registrering af Hærvejens mange kulturhistoriske levn med henblik på etablering af et sammenhængende stisystem for den gående og cyklende trafik. Etablering af et grønt stianlæg ned langs Jyllands rygrad skulle give brugeren en fornemmelse af, hvorledes det var at færdes i gamle dage. Registreringen skulle følges op af en mere omfattende fredning for at sikre de mange truede spor (specielt spor af hulveje og hjulspor) af vejen. Endelig skulle etablering af et stisystem følges op af faciliteter for harvejsturisterne. ${ }^{2}$

I perioden fra 1975 til 1983 blev gruppens forslag fulgt op af Mads Lidegaards systematiske undersøgelse af Hærvejens mange kulturhistoriske spor. Resultatet af denne undersøgelse er publiceret i Lidegaards seks bøger om Hærvejen. ${ }^{3}$ Mads Lidegaards rekognoscering blev økonomisk støttet af fredningsstyrelsen. På fredningsstyrelsens initiativ foretog Henrik Becker-Christensen i perioden fra 1979 til 1980 en undersøgelse af Hærvejen i Sønderjylland. Resultatet af dette arbejde er senere publiceret i bogen »Hærvejen i Sønderjylland ${ }^{4}{ }^{4}$ Sideløbende med dette arbejde har de implicerede institutioner foretaget særskilte undersøgelser. Viborg, Vejle, Sønderjylland, Århus og Ringkøbing amter har således udarbejdet analyser og stiplanforslag for Hærvejen, mens fredningsstyrelsen har foretaget registreringer af de kulturhistoriske spor, særligt af gamle vadesteder, broer og voldanlæg. ${ }^{5}$ Resultaterne af dette arbejde blev i 1982 opsummeret i Hærvejsgruppens anden rapport, der primært er et koncentrat af Lidegaards resultater. ${ }^{6}$ Ved et møde i september 1980 blev det besluttet, at fredningsstyrelsen i sine udtalelser om regionplanforslagene skulle henstille, at der ikke blev foretaget dispositioner, som var til hinder for en fremtidig etablering af et regionalt stinet ned langs Hærvejen. Endvidere skulle 
Hærvejsstrøget sikres i den kommende fredningsplanlægning. ${ }^{7}$ Siden Hærvejsgruppens anden rapport er disse initiativer fulgt op i såvel den amtslige som den kommunale planlægning. Om Hærvejen i Vejle Amt hedder det således: "Hærvejen er udlagt som beskyttelsesområde for kulturhistoriske interesser og som rekreativ stirute med heraf følgende retningslinier ... Hærvejsstrøget er et vigtigt kulturspor i Vejle Amt og beskyttelsen og formidlingen heraf skep ved en række planlægningsinitiativer $\ll{ }^{8}$ Regionplanernes hensigt er senere fulgt op af en række initiativer. Således har amtskommunerne i fællesskab skabt en række gode afmærkede stiruter for cyklister ned langs Hærvejen. Samtidig har amterne udsendt tre cykelguider med de væsentligste historiske og kulturhistoriske oplysninger om Hærvejen samt en række praktiske oplysninger for cyklisterne. ${ }^{9}$ Dette arbejde vil i de kommende år blive fulgt op af tilsvarende stisystemer og guider for vandrere. ${ }^{10}$

\section{Hugo Matthiessen og Hærvejen}

1970erne og 1980erne har således været præget af et forskningsmæssigt boom efterfulgt af en række amtslige initiativer af fredningsmæssig og turistmæssig karakter. Til trods for den dybe folkelige fascination siden udgivelsen af Hugo Matthiessens bog om Hærvejen i $1930^{11}$ er det sparsomt, hvad der er præsteret af forskning indtil midten af 1970erne. Størsteparten af den eksisterende forskning omhandler enkelte emner og områder, smårevisioner af den eksisterende forskning. En af forklaringerne på den sparsomme forskning, kan være den monumentale betydning, forskningsmæssigt og folkeligt, som bogen har haft op til i dag. Anders Linde-Laursen skriver i sin bog om Hugo Matthiessen, at han formåede at fremstille "punctum «. ${ }^{12}$ "Hærvejen « er et sådant punctum, men samtidig satte den et punktum for den videre forskning om Hærvejen. Inden for historikerlauget har de fleste med bogen Hærvejen betragtet emnet som udtømt, samtidig med at emnet i sig selv faldt uden for fagets traditionelle forskningsfelt. I den forbindelse er det karakteristisk for den forskningsmæssige situation, at Hugo Matthiessens billeder af Hærvejen fra 1926 til 1929 er den eneste systematiske fotoregistrering, som Nationalmuseets 2. afd. har foretaget. Siden 1930 er det kun blevet til enkelte billeder primært i forbindelse med restaureringsarbejder. Folkeligt blev «Hærvejen» Hugo Matthiessens mest solgte bog. Siden 1930 er bogen udkommet i 14 oplag, hvoraf det sidste oplag meget betegnende for den folkelige interesse netop er udkommet fornylig (1990). Hugo Matthiessens bog er fortsat, trods Mads Lidegaards grundige undersøgelser, bogen om Hærvejen. 


\section{Hærvejen, studevejen eller oksevejen}

Hugo Matthiessen havde mange navne at vælge imellem, da han skulle navngive vejen. "Oksevejen « blev den kaldt syd for Kongeåen, mens man nord for åen brugte navne som "Studevejen«, "Kongevejen«, "gammel Viborgvej«, "Adelvej« og "Alvej«. ${ }^{13}$ Bemærkelsesværdigt nævner han på intet tidspunkt "Hærvejen«, som stednavn for hele vejen endsige for dele af vejen mellem Viborg og Dannevirke, hvilket man kunne forvente $i$ betragtning af bogens titel. Det er formentlig ikke uden grund. "Hærvejen« findes ikke brugt som stednavn, før Hugo Matthiessen anvendte det i 1930. Oprindeligt blev ordet $i$ middelalderen anvendt som en betegnelse for en hovedlandevej. I Jyske Lov betegnes de større veje 'konings hærræ strathæ'. ${ }^{14}$ I senmiddelalderen glider dette udtryk ud til fordel for bl.a. "alfarvej«. På tilsvarende vis anvendte man på samme tid »hærstræde« om en hovedgade eller hovedlandevej..$^{15}$ I nyere tid er Johannes Mejers kort fra 1649 det eneste sted, hvor ordet optræder. I hans kort over Haderslev østeramt, anvender han betegnelsen "Rechte herr weg" om vejstykket mellem Immervad og Vedsted. Ordet »herr weg“ optræder imidlertid på flere vejstrækninger, bl.a. vejstrækningen mellem Tønder og Haderslev samt alfarvejen mellem Sorø og Ringsted, der bærer påskriften "heer-wegh «. ${ }^{16}$ Tager man $i$ betragtning, at Johannes Mejer talte tysk, hvilket i udstrakt grad præger navnene på hans kort, er der god grund til at formode, at ordet anvendes i den middelalderlige betydning som alfarvej. Denne antagelse bestyrkes, når man i Casper Danckwerths ledsagetekst til vejstykket mellem Immervad og Vedsted kan læse: njammerwatt worselbsten die Heerstrasse nach Coldingen und dem Reich Dennemarck daüber gehet $\ll .{ }^{17}$ Her anvendes altså ikke »herr weg «, men derimod »Heerstrasse $«$. At hævde som Hugo Matthiessen og Bjørn Svensson, at det skal oversættes til den »rette« eller »rigtige« hærvej giver derfor ingen mening. ${ }^{18}$ Som det fremgår af kortudsnittet s. 25 deler vejen fra »æ vold« til Vojens sig i to vejføringer, en vestlig og en østlig. Jeg finder det derfor rigtigt, som Henrik Becker-Christensen narmere argumenterer for i denne årbogs næste artikel, at betragte »Rechte herr weg« som den højre hovedlandevej i modsætning til den venstre fra Haderslev til Immervad. Stednavnet Harvejen er med andre ord skabt af Hugo Matthiessen selv, og på baggrund af det svage kildemæssige belæg havde han måske gjort forskningen en tjeneste ved at opkalde vejen efter sin funktion enten "studevejen « eller »oksevejen«. 


\section{Vejen før og nu}

"Der gaar en gammel Vej ned gennem Jylland. Den hører hjemme inde paa Halvøen, og som den færdes der, har den unægtelig selv ikke saa lidt af Befolkningens Sind i sig; thi sejgt og vedholdende som en Jyde slider den sig taalmodigt mod Vejsende. Men dens Stædighed grænser til Stivsind, den slipper ikke sit Maal af Syne, hvor stærkt Forholdene end har forandret sig, og den lader sig ikke anfægte af, at man i vore Dage paa lange Stræk, hvor det har været fordelagtigt, har rettet dens krogede Krop ud efter en Snor og stoppet dens Indre med skærver og Grus. $\aleph^{19}$

Således starter Hugo Matthiessen på sin karakteristiske facon sin bog om Hærvejen. For Hugo Matthiessen var Hærvejen et fast defineret stykke vej, der under hans hænder fik sjæl og krop. Derfor kunne han trække en linie ned igennem Jylland, som han kaldte Harvejen. I hans mere teoretiske overvejelser om fortidens veje var han imidlertid inde på en anden opfattelse af begrebet "vej«. Således skrev han få år før, at fortidens mennesker brugte ordet »vej« som sømændene i dag, nemlig til at betegne punkter man var vant til at passere for at drage fra et punkt til et andet. ${ }^{20}$ Ruten mellem de to punkter kunne den rejsende selv vælge. I »Hærvejen« træder denne betragtning af ordet vej imidlertidig tilbage for den nutidige opfattelse af ordet, som et bestemt defineret forløb mellem to punkter. Hugo Matthiessens arbejde bestod derfor $i$ at skille spor fra den gamle Hærvej ud fra spor af andre vejsystemer. Det er et arbejde, som stadig volder problemer, når man som Matthiessen betragter Hærvejen som en vej i moderne forstand.

Peter Seeberg har i et efterskrift til den 3. udgave af bogen beskrevet en lille episode. Episoden foregik i Thorning, hvor Hugo Matthiessen havde aftalt at mødes med folk, der var uenige om Hærvejens forløb. Da Hugo Matthiessen mødte op, forlod den ene part stedet og lod den anden besnakke Hugo Matthiessen til fejl og misfortolkninger. Siden denne episode eksisterer der stadig to fortolkninger af Hærvejens forløb i Thorning. Opfattelsen af Hærvejen som et bestemt defineret stykke vej har været enerådende indtil begyndelsen af 70erne, hvilket har præget debatterne om Hærvejens forløb. Indlæggene har formet sig som korrektioner til Matthiessens resultater om Hærvejens rette forløb. Således har vejforløbet fra Jelling til Immervad været genstand for en livlig debat. Specielt er stykket mellem Kongeåen og Immervad karrig med spor. Hugo Matthiessen mente, at vejen fortsatte fra Bakke over Laborg og Vejen til Skodborghus, hvor den passerede Kongeåen. Herfra fortsatte den over Jels, Oksenvad, Sommersted hede og videre ad Vojens til Øster Immervad. Matthiessen lagde i sin argumentation vægt på, at den store Farrisskov havde tvunget Hærvejen mod vest. ${ }^{21}$ Dette synspunkt er siden blevet fulgt af P.V. 


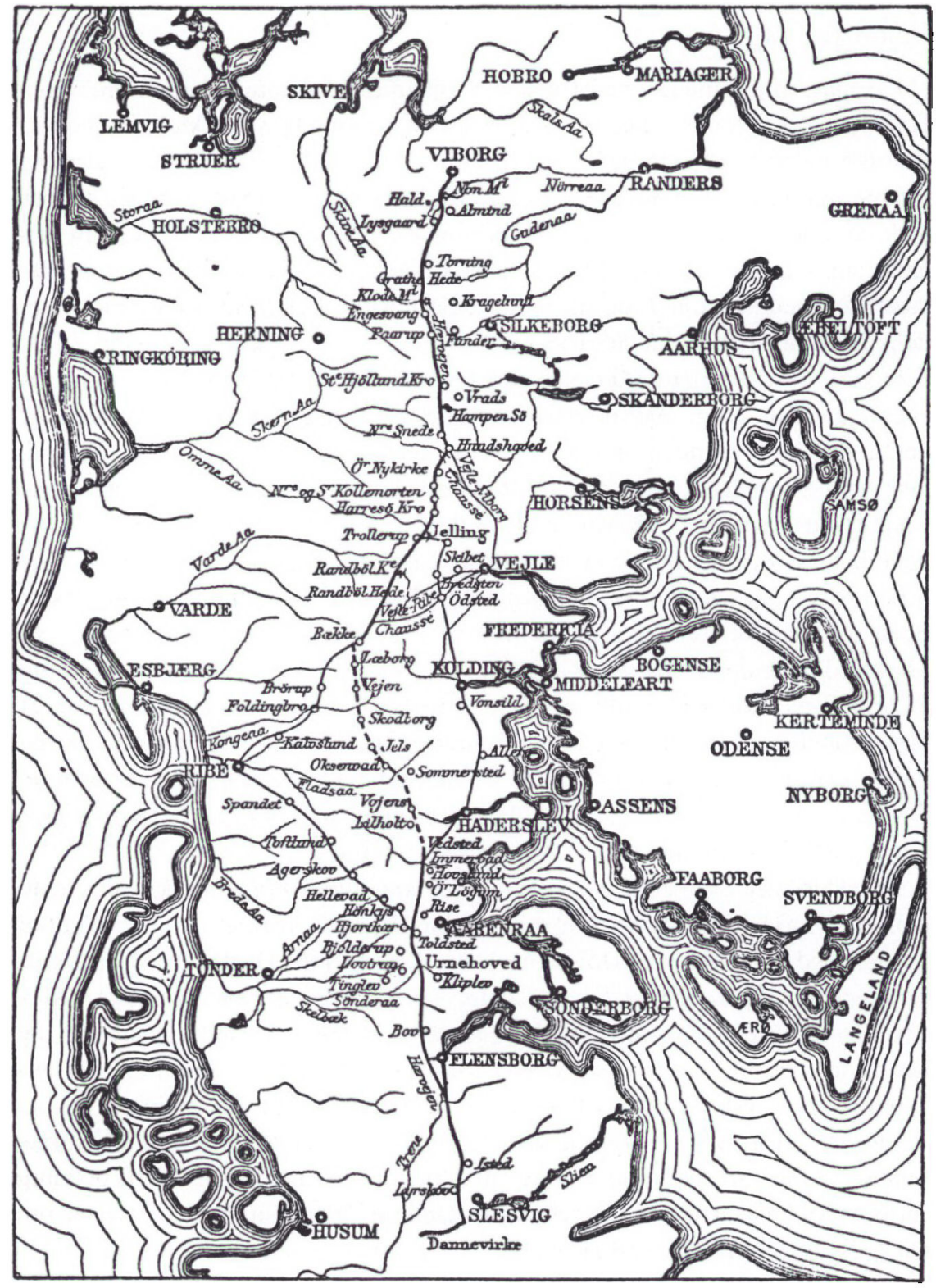

Hugo Matthiessens beromte kort over Harvejen. Gengivet efter Hugo Matthiessen (1930/81), s. 13. 
Glob, H.V. Gregersen og Mads Lidegaard, de sidste to med enkelte korrektioner. ${ }^{22}$

I opposition til denne opfattelse har Bjørn Svensson hævdet, at Hærvejen ikke gik over Skodborghus, men i stedet fulgte to ruter, henholdsvis en mod vest over Foldingbro til Ribe og en mod øst til Kolding. ${ }^{23}$ Mads Lidegaard har endvidere ment at kunne spore en østlig gren fra Egtved over Kongeåen ved Vamdrup videre til Vojens. ${ }^{24}$ Fælles for de mange opfattelser af Hærvejens forløb har været en stærk fokusering på de forskellige vejstykkers alder. Kildematerialet levner kun få og usikre muligheder for en egentlig datering af de enkelte vejstykkers alder. Hovedproblemet er, at de mange spor $i$ landskabet ikke i sig selv giver oplysninger om deres alder og funktion. De hjulspor, der synes at være en del af Hærvejen, kan være et resultat af bondens transport til det nærliggende marked, og selv om det lykkes at finde en sikker datering, giver det ingen garanti for, at vejen stadig havde den samme betydning. Hovedvejen kan f.eks. være blevet reduceret til en bivej.

Personligt tror jeg, der kan være grund til, på baggrund af de seneste års forskning, at lægge større vægt på de enkelte vejstykkers funktion. Bjørn Svensson skriver således: "Studedrifterne kan passere over Kongeåen ved Gredstedbro og Foldingbro, men altid med fortoldning i Ribe, og i øst skal fortoldningen ske i Kolding. Kongeåen og Kolding å presser således stadig vejsystemet ud $\mathrm{i}$ øst og vest, hvorved det ældgamle diagonalvejsprincip opretholdes i Sønderjylland, hvor vejene først samles i den traditionelle hærvej syd for Immervadene ${ }^{25}$ Det var med andre ord statens toldsteder i Kolding og Ribe, som siden 1475 tvang studetrafikken mod øst og vest.

Den forklaring forudsætter, at studedrifterne rent faktisk har passeret de to toldsteder. Dette var ikke altid tilfældet, hvilket de mange smuglerhistorier langs Kongeåen godtgør. I 1572 blev Tulle Iversen fritaget for at svare fæsteafgifter af sin fæstegård til Skodborghus mod at passe på, at der ikke blev smuglet kreaturer og heste over de ulovlige vadesteder mellem Kolding og Skodborg. Den 25. oktober 1574 modtog lensmanden på Koldinghus Vincens Juul et åbent kongeligt brev. Kongen havde erfaret, at mange gik uden om de kongelige toldsteder i Kolding og over »den mellem Skodborg og Kolding løbende Aa . For at komme dette smugleri til livs fik Vincens Juul befaling til at stille købmændene for retten og dømme dem til galgen. ${ }^{26}$ Truslen om galgen synes ikke at have haft nogen effekt.

I perioden 1764-1766 foretog Generaltoldkammeret en tælling af de stude, der var anmeldt til opstaldning i vinteren for at blive solgt det følgende forår, og de stude, som det folgende forår rent faktisk blev opgivet til fortoldning ved toldstederne i Kolding og Ribe. Valger man at tro de officielle statistikker, var det kun hver anden staldøksne, der blev solgt ved de store markeder $\mathrm{i}$ 


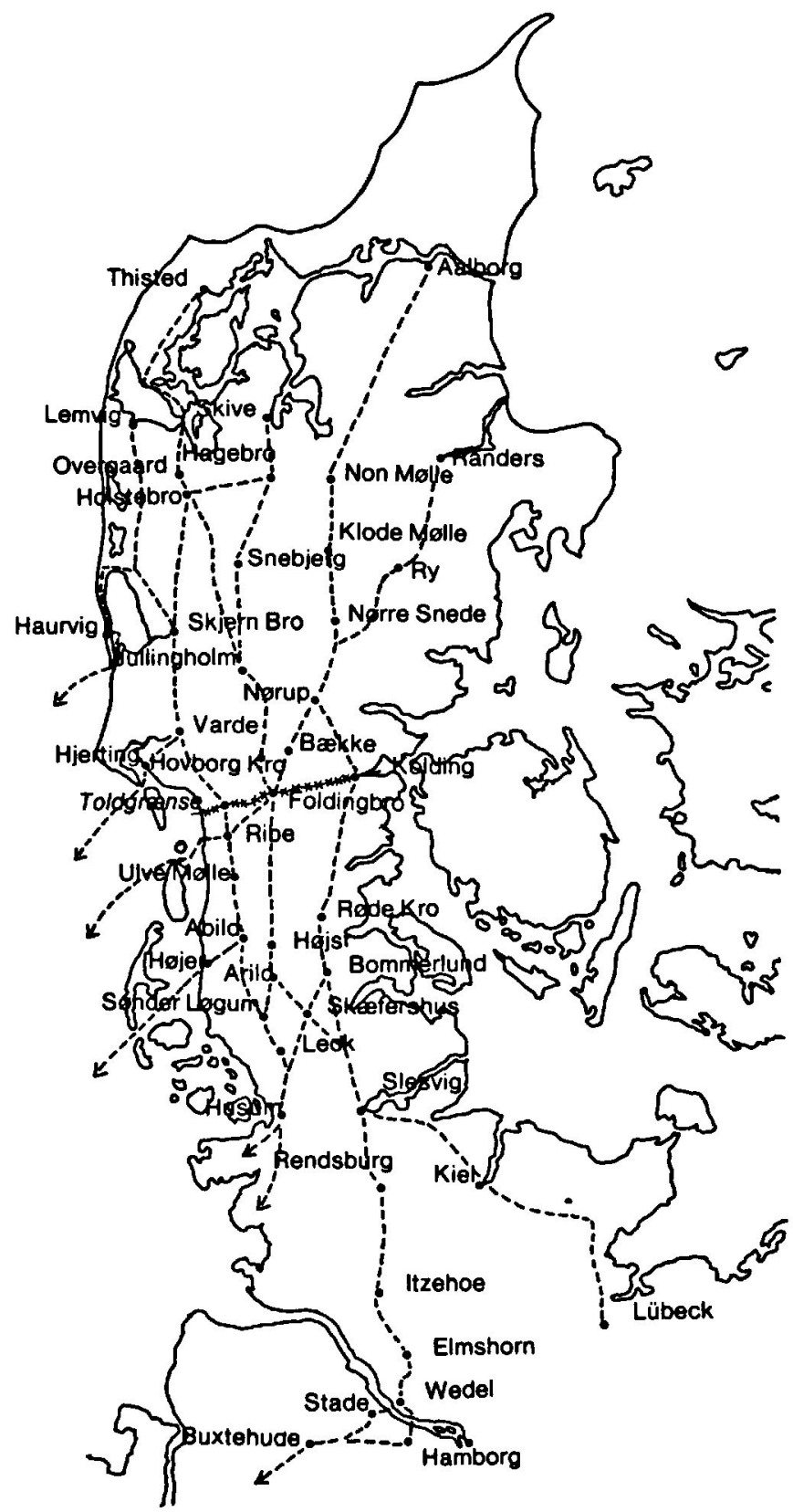

De nord-sydgdende studedrivveje $i$ Jylland. Kortet er udarbejdet på grundlag af oplysninger fra H.F.Feilberg, H.V.Gregersen, Jesper Madsen, J.Sandholm samt H.Wiese \& J.Bölts. Gengivet efter Johannes Mollgaard 1988, s. 92. 
Hertugdømmerne. Tallene er naturligvis udtryk for den rene toldsvindel. 56.573 stude blev opfodret de tre år, men kun de 25.794 blev anmeldt til toldstederne i Kolding og Ribe. Ingen gårdmand ville fodre en stud op, som ikke blev solgt ved det følgende forårsmarked. Differencen fortæller med andre ord om omfanget af smugleriet over Kongeåen. Med til dette billede hører, at antallet af anmeldte stude $i$ sig selv er et minimum. Der var altså rigeligt med stude, som benyttede de 36 broer og vadesteder over Kongeåen mellem toldstederne i Kolding og Ribe, omend ingen af de udaterede vadesteder har kunnet knyttes til en bestemt historisk vejføring. I de fire år fra 1778 til 1782, hvor toldkontrollen langs Kongeåen var kraftig forstærket, blev knap 1/4 af de 39.000 græsstude, der totalt blev eksporteret i perioden 1700-1787, ført ud af landet! ${ }^{27}$

Forholdet mellem opstaldede og fortoldede stude. 1764-1766.

\begin{tabular}{lccc}
\hline àr & $\begin{array}{c}\text { antal anmeldte opstaldede } \\
\text { stude }\end{array}$ & $\begin{array}{c}\text { antal anmeldte stude til for- } \\
\text { toldning samme àr }\end{array}$ & $\begin{array}{c}\text { difference mellem opstaldede } \\
\text { og fortoldede stude }\end{array}$ \\
\hline 1764 & 19.672 & 9.315 & 10.357 \\
1765 & 17.330 & 7.776 & 9.554 \\
1766 & 19.571 & 8.703 & 10.868 \\
\hline I alt & 56.573 & 25.794 & 30.779 \\
\hline
\end{tabular}

Kilde: RA. Generaltoldkammeret. 1773-91. Fynske og jyske toldkontorer. "Sager om studehandelen i Jylland og toldgransen mellem kongeriget og Slesvig 1776-77«.

Helt uden dokumentation, som hævdet af Bjørn Svensson, er Hugo Matthiessens påstand om en Hærvej over Skodborghus imidlertid ikke. I en befaling fra 1579 forklares det, hvorledes studehandlerne i Foldingbro skulle bevise, at det var deres hensigt at betale told i Ribe: "Da det gaar meget uskikkeligt til med Oppebørslen af Told ved Foldingbro, skal alle, der vil føre Øksne, Køer, $\mathrm{F}$, Heste, Øg og Foler over her, først fortolde det paa Skodborg Slot og fremvise Slotsfogedens Toldseddel for Bromanden ved Foldingbro. Slotsfogeden paa Skodborghus skal saa hvert Aar gøre Tolderen i Kolding Regnskab for Tolden ${ }^{28}$ Kravet betød en besværlig omvej for studedrifterne. Der er derfor rimelig grund til at antage, at kravet havde baggrund $i$ en allerede eksisterende trafik over Skodborghus af betydeligt omfang.

Ordningen kom næppe i funktion. Skodborghus slot blev i 1580 mageskiftet over i privat eje. Indtil slutningen af 1700-tallet var der kun tre steder, Gredstedbro, Foldingbro og Koldingbro, hvor det var muligt lovligt at drive studene over. På baggrund af indberetningerne til Generaltoldkammeret blev det i 1776 muligt efter en anmeldelse hos stiftamtmanden i Ribe at drive studene over ved Skodborghus. Kort tid efter blev der på tilsvarende vis lavet tre nye overfartssteder ved Ejstrup, Dollerup og Vilslev. Samtidig med 
åbningen af disse nye overfartssteder blev der ansat 10 betjente, der skulle kontrollere toldgrænsen.

På et tysk kort fra ca. 1850 kan man finde en vej, som fører over Kongeåen via Skodborg, videre vest om Jels, til et sted p̊ Hærvejen syd for Jels formentlig mellem Sommersted og Vojensgård. ${ }^{29}$ Nord for Kongeåen deler vejen sig $i$ to. En vestlig mod Foldingbro og en østlig mod Andst. Derimod viser kortet ikke den af Hugo Matthiessen hævdede del af Hærvejen fra Bække over Læborg, via Vejen til Skodborghus. Kortmaterialet gør det ikke muligt at angive vejens status, men signaturen rangerer vejen på lige fod med landevejen fra Bække over Foldingbro til Ribe, altså ikke en ubetydelig landevej. På tilsvarende vis genfinder man vejstykket fra Skodborg over Jels til Sommersted hede på Videnskabernes Selskabs kort, mens vejstykket fra Skodborg over Kongeåen til Vejen er aftegnet som en sti. Ved Skodborghus krydses stien af en landevej fra Foldingbro til Andst. Vejens (stiens) alder og funktion kan man kun gisne om, men det kan være en del af den gamle Hærvej, som ved oprettelsen af toldstederne i Kolding og Ribe efter middelalderen mistede sin officielle status og kun blev opretholdt i kraft af en uofficiel status som smuglerrute for studedriverne. De mange vadesteder og spor af vejstykker kan derfor i princippet være "samtidige alternative « ruter bestemt af de skiftende årstider, vejrforhold, rejsemåde og ikke mindst af muligheden for smugleri over Kongeåen.

I fredningsplanlægningen har denne opfattelse af ordet vej som et fast defineret vejstykke været dominerende. Fredningen har været lagt an på at frede ganske bestemte og veldefinerede vejstykker, der ifølge Matthiessen kunne betragtes som den oprindelige Hærvej. Dette er f.eks. tilfældet for det fredede vejstykke mellem Hundshoved over Øster Nykirke til Kollemorten samt et stykke ved Givskud. ${ }^{30}$

\section{Vejkorridor}

I begyndelsen af 1970erne skete der et brud i den dominerende opfattelse af ordet "vej«. Grundlæggende i dette nybrud er Alex Wittendorff behandling af det danske vejsystem $\mathrm{i} »$ Kongevej og Alvej«. Med Wittendorffs disputats var det wi almindelighed trafikken selv, der skabte vejene, og de hyppigst anvendte trafikmidler blev derfor afgørende for selve vejbanens udformning ${ }^{31}{ }^{11} \mathrm{Ny}$ er denne erkendelse egentlig ikke. Den findes som allerede nævnt hos Hugo Matthiessen, og også hos andre kulturhistorikere. ${ }^{32} \mathrm{Ud}$ fra denne betragtning var vejen identisk med de hjulspor, vognene sled ned i terrænet. Undertiden kunne hjulsporene blive kørt så meget op, at undervognen sad fast i mudderet. De kørende måtte derpå til at køre ved siden af de gamle hjulspor eller finde 


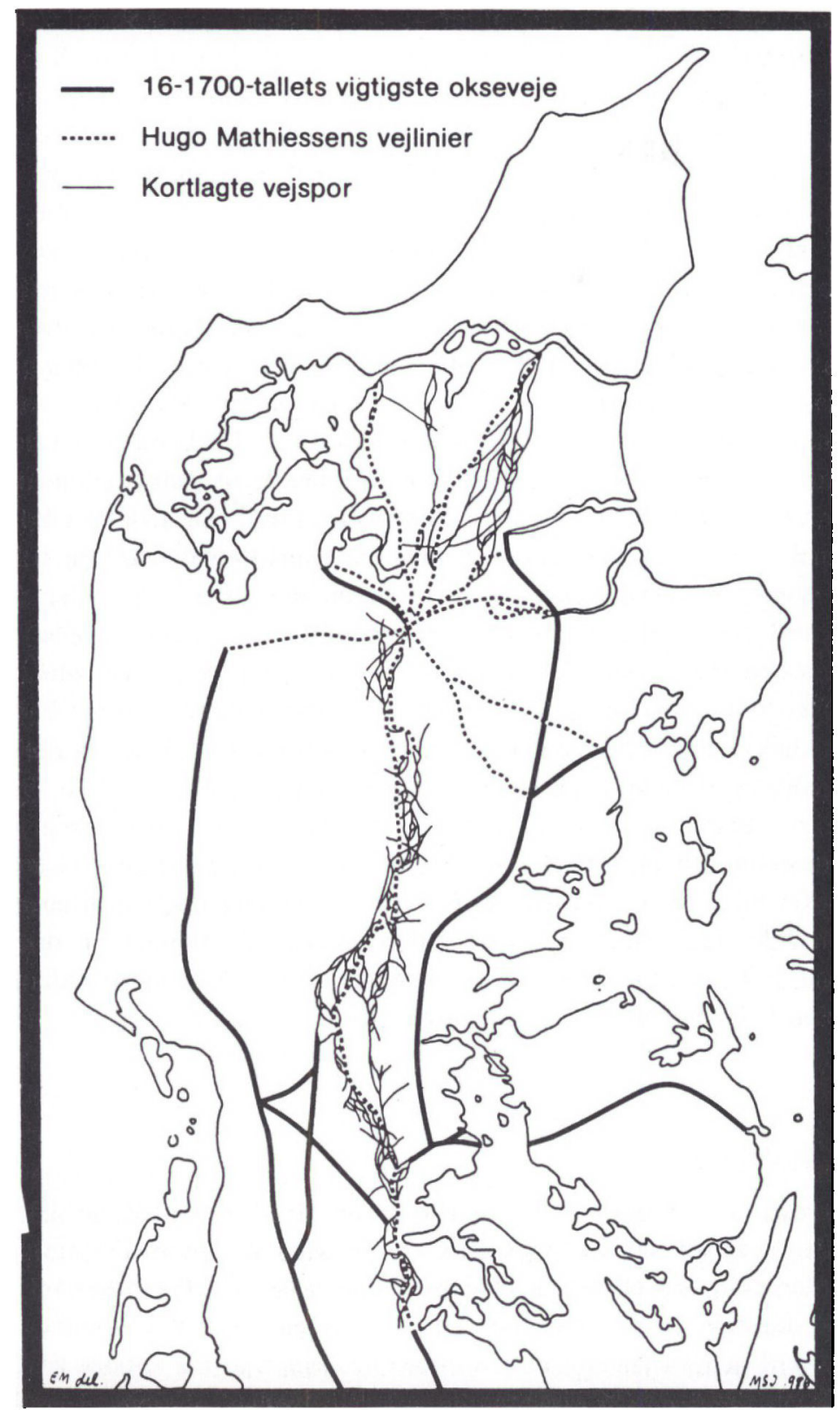

Hugo Matthiessens vejlinier, den ostlige og vestlige studedrivvej. Som det fremgår af kortet, ville Jylland blive fyldt med vejspor, hvis der var foretaget tilsvarende minutiose registreringer af vejspor langs den vestlige og astlige drivvej, som dem Mads Lidegaard har foretaget af Harvejen. Gengivet efter Peder Mortensen \& Birgit M. Rasmussen 1988, s. 105. 
helt nye vejforløb. Vejen kunne på denne måde over længere tid opnå en bredde på flere kilometer. Når vejenes forløb på denne måde var en funktion af trafikken, må det få konsekvenser for vores forståelse af Hærvejen.

Mads Lidegaard har taget den fulde konsekvens af denne erkendelse. I sine seks Hærvejsbøger har han systematisk registreret samtlige spor, Hærvejen som hovedvej for studedrivningen har sat sig i kulturlandskabet. Mads Lidegaard har på denne måde dokumenteret, at Hugo Matthiessens Hærvej var en »valgt« vej. Én ud af flere mulige veje som den rejsende kunne vælge mellem fra Viborg til Flensborg. Den nyeste vejhistoriske forskning har med andre ord taget konsekvensen af Hugo Matthiessens mere teoretiske betragtninger omkring veje og vejforløb. Lis Helle Olesen og Torben Skov har i »Oldtidsvejen « anvendt ordet "vejkorridor" om bæltet, inden for hvilken den rejsende, alt efter årstid, vejrforhold, rejsemåde og for Hærvejens vedkommende mulighederne for smugleri, kunne vælge forskellige ruter. ${ }^{33}$ Jeg tror, der kan være grund til $\mathrm{i}$ højere grad end hidtil at tage dette ord $\mathrm{i}$ anvendelse for at undgå uvedkommende associationer til det moderne vejsystem. ${ }^{34}$ Samtidig må dog indrømmes, at begrebet meget let bliver udvandet, hvis man tager alle sporene med. Lægger man, som Mogens Schou Jørgensen har gjort det, Mads Lidegaards kortlagte Harvejsspor ind på et kort over Jylland, vil man hurtigt få plastret hele Jylland ind $\mathrm{i}$ vejspor, især hvis man samtidig foretog tilsvarende kortlægninger af de vestjyske og østjyske drivveje. ${ }^{35}$

Det nye begreb wvejkorridor " har sat afgørende spor $\mathrm{i}$ den igangværende fredningsplanlægning. I stedet for den tidligere fredning af enkelte bestemte vejstykker med tilstødende arealer har det været nødvendigt med en bredere fredning, der tager højde for hele vejkorridoren og de områder, den løber igennem. Netop dette udgangspunkt ligger til grund for de naturfredningsforslag, som Hærvejsgruppens anden rapport mundede ud i.

\section{Pilgrimmens horisont}

Matthiessen valgte $\mathrm{i}$ sin disposition af bogen at følge den islandske abbed Nicolaus, der i sin vejviser for pilgrimsrejsende beskrev, hvorledes man på syv dagsrejser kom fra Viborg til Hedeby. Bogens syv kapitler beskriver derfor hver en dagsrejse og de oplevelser, en moderne Romafarende kommer ud for på sin færd ned ad Hærvejen. "Romfarerne regner, at fra Ålborg er 2 dages rejse til Viborg, derpå en uges rejse til Hedeby, hvorfra der er kort til Slesvig, ...... ${ }^{36}$ Hos Adam af Bremen hedder det: "Den første Del af Danmark, som hedder Jylland, strækker sig fra Ejderen i Længderetning mod Nord og maaler 3 Dagsrejser, hvis man drejer af til Fyn; men hvis man tilbagelægger Vejen fra 


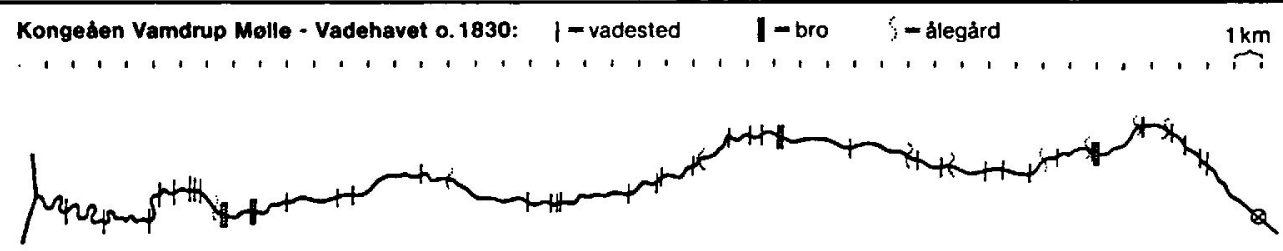

Overgangssteder over Kongeden mellem Vamdrup molle og Vadehavet efter kort fra ca. 1830 i Landsarkivet $i$ Viborg. Her gengivet efter Mogens Schou Jorgensen i: Peder Mortensen \& Birgit M. Rasmussen 1988, s. 107.

Slesvig til Aalborg i lige Linje, saa har man 5 eller 7 Dagsrejser. Det er Kejser Ottos Vej lige op til Vendsyssel..... ${ }^{37}$ Senere forfattere ikke mindst af de mange turistfoldere og korte vejledninger om Hærvejen har fulgt denne disposition af stoffet og ikke helt uden ret.

Jeg vil dog på dette punkt gerne lege djævlens advokat og advare mod dette Romperspektiv. Det kan være godt i en moderne turistfolder, men for Hærvejsforskningen forbliver udsynet den ensomme pilgrimsrejsendes - eller den moderne cykelturists - horisont. Der er skrevet og talt meget om Harvejen som Romavej, men kildemæssigt findes der kun to kilder, der taler om vejen som pilgrimsvej, og de udmærker sig ikke ved deres præcision. I deres kerne siger de kun, at der er syv dagsrejser fra Viborg til Hedeby. Det er ikke min hensigt at benægte eksistensen af en Romavej. Min pointe er, at Matthiessen skrev om en ud af flere veje ned gennem Jylland, men allerede den samtidige litteratur så Matthiessens Hærvej som blot den midterste af tre drivveje ned igennem Jylland. ${ }^{38}$ Horisonten i bogen er primært pilgrimmens, ikke studedriverens (der heller ikke kunne tilbagelægge strækningen på syv dage) for hvem vejen var knap så fast defineret, eller forskerens. Derved er bogen desværre kommet til at stå som en rejseguide isoleret fra den øvrige forskning.

\section{Endepunkterne og studehandelen}

I stedet for alene at fokusere på selve vejen kan der være god grund til samtidig at se på de to punkter vejen forbinder. Det er endepunkterne, der bestemmer behovet for en vej og dens forløb. Johannes Møllgaard har netop i en artikel "Det 'mørke' Jylland og 'verdensmarkedet' " ${ }^{39}$ beskæftiget sig med endepunkterne af Hærvejen. Møllgaards udgangspunkt er den etablerede opfattelse af Jylland, som det 'mørke' Jylland og de fordomme om Jylland og jyder, som knytter sig dertil. 


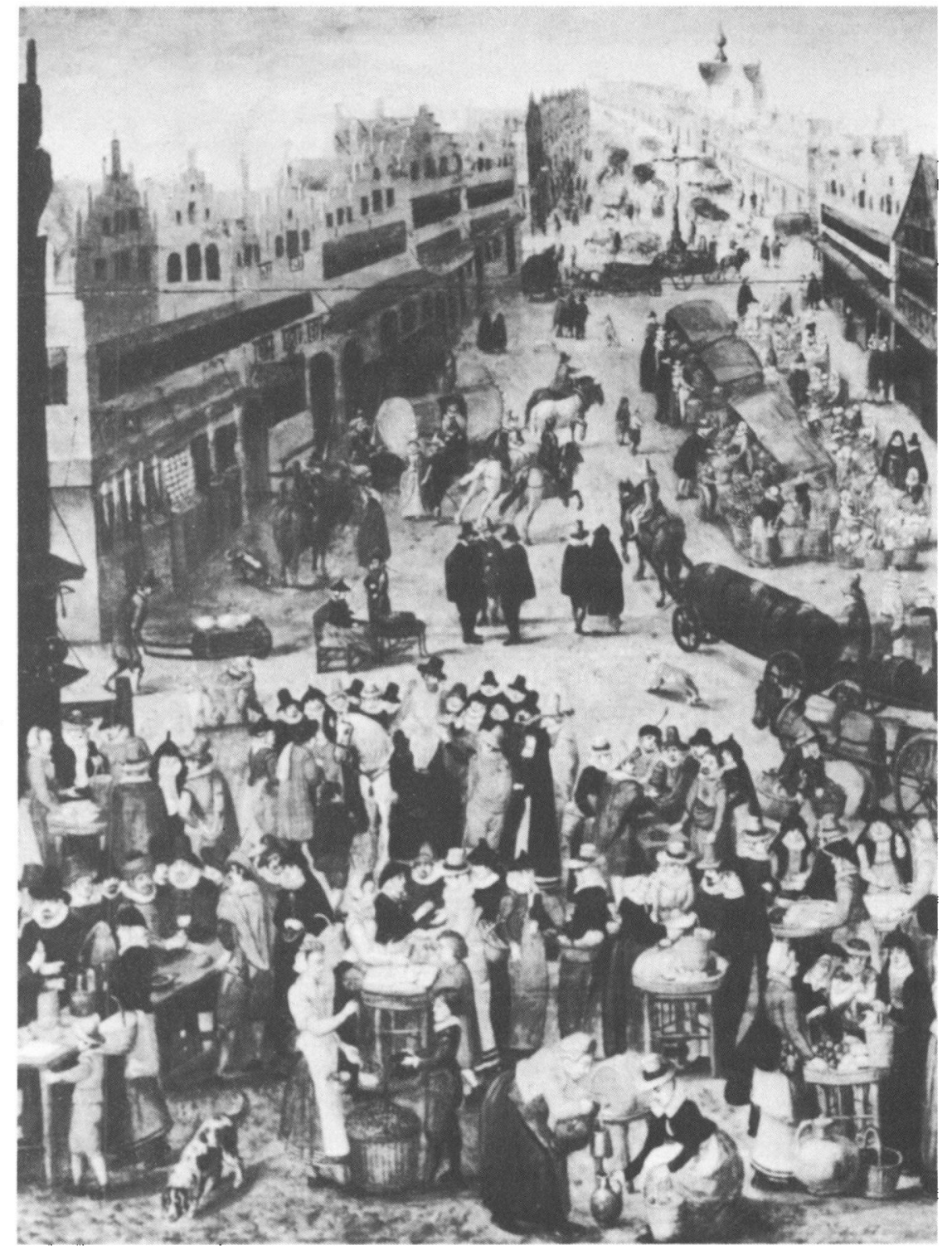

I senmiddelalderen var Danmark led $i$ et okonomisk samspil over lange afstande. Til Nederlandene solgtes stude, og korthart klade var en af returvarerne. Pà den màde blev Nederlandenes byer en del af Danmarks horisont. Her en markedsscene fra Antwerpen sidst i 1500-ärene. Gengivet efier Fernand Braudel: Civilization and Capitalism 15th-18th Century, 1979/82 bd. 2 s. 56. 
For at komme rundt om disse fordomme har han foretaget en analyse af den jyske studehandel fra middelalderen og op til midten af 1800-tallet med anvendelse af Wallersteins center-periferisystem. ${ }^{40}$ Ifølge Møllgaard blev Jylland i senmiddelalderen inddraget i det moderne verdenssystem, som leverandør af stude til de store økonomiske magtcentre i Nederlandene. I denne fase udnyttede jyderne deres ekspertise inden for kvægbrug. De specialiserede sig i studeopdræt for at klare sig i konkurrencen med de øvrige periferiområder i Europa. Centralt i den stærkt specialiserede produktion stod en omfattende handel med stude internt bønderne imellem, mellem bønderne og adelen $i$ Jylland og eksternt handel med købmændene ved de store markeder i Wedel og senere Husum. Resultatet af denne proces blev et landbrug, der var rettet imod studeproduktion, bl.a. med en stor vagt på dyrkning af havre til kreaturerne og ikke mindst en jysk bondekultur, der på en række centrale punkter adskilte sig fra den sjællandske. I Jylland blev den ansete bonde lig med den succesrige handelsbonde. Den omfangsrige kreaturhandel, der var en nødvendig del af kvægproduktionen, gav med Møllgaards ord »jyderne deres vigtigste kulturelle særpræg. Den førte til mindre solidaritet, større individualisme og større foretagsomhed “. ${ }^{41}$ På disse og en række andre kulturelle træk skilte den jyske bonde sig ud fra sine sjællandske standsfæller. Mest udpræget var disse træk syd for Kongeåen. Som en bibetragning antyder Møllgaard bl.a., at vornedskabet ikke kunne indføres i Jylland, da det ville gribe afgørende ind $\mathrm{i}$ centrale dele af kvægproduktionen.

Dette kortfattede referat yder ikke Møllgaards artikel fuld retfardighed, men understreger verdensmarkedets afgørende betydning for det jyske landbrug og jysk bondekultur. Set i det perspektiv bliver Hærvejen eller studevejen, som jeg foretrækker at kalde den, af afgørende betydning, som bindeled mellem Europas centrum og Nordjylland. Jeg vil hævde, at Hærvejen set i dette lys, bliver det perspektiv, der flytter udsynet fra pilgrimmens horisont og i stedet bliver en linse til belysning af jysk historie og jysk kulturhistorie. 


\section{NOTER}

1. »Hærvejen. Rapport $1 \ll 1976$, s. 7.

2. ibid. s. 7 ff.

3. Lidegaard, Mads 1975, 1976, 1977, 1979, 1980 og 1983.

4. Becker-Christensen, Henrik 1981.

5. »Hærvejen. Rapport 2« 1982, s. 3.

6. ibid.

7. ibid. s. 4.

8. Vejle Amtkommune 1989, s. 68.

9. Hærvejen på cykel $1989 \mathrm{a}, 1989 \mathrm{~b}, 1989 \mathrm{c}$.

10. Stiplaner: Sønderjyllands Amtskommune 1984.

Vejle Amtskommune 1986.

Viborg Amtskommune 1978.

Arhus Amtskommune 1982.

11. Hugo Matthiessen: »Hærvejen« Kbh. 1930. Bogen er siden udgivelsen i 1930 udkommet i 14 oplag. Et misundelsesværdigt oplagstal for en historiker.

12. Anders Linde-Laursen 1989, s. $7 \mathrm{ff}$.

13. Hugo Matthiessen 1930, s. 8.

14. Alex Wittendorff 1973, s. 10.

15. Ordbog over det danske sprog bd. 8, 1926, sp. 1113.

16. Alex Wittendorff 1973, s. 10 og Bjørn Svensson 1967b, s. 210.

17. Bjørn Svensson 1967b, s. 210.

18. Hugo Matthiessen 1930, s. 102 og Bjørn Svensson 1967b, s. 219. H.V. Gregersen har ikke kunnet finde belæg for brug af ordet Hærvej før 1627. Dette år skriver amtsskriver Peter Moritzen, at alt var kaos på Toldsted vest for Ábenrå, „Weile an der Heer-Strassen Niemant bleiben kan«, H.V. Gregersen 1976, s. 14, note 18.

19. Hugo Matthiessen 1930, s. 7.

20. Hugo Matthiessen 1927, s. 109 .

21. Hugo Matthiessen 1930, s. 99.

22. P.V. Glob 1934, s. 242f, H.V. Gregersen 1976, s. 12f, Mads Lidegaard 1979, s. 10, 29-37.

23. Bjørn Svensson 1967a, 1967b, 1984.

24. Mads Lidegaard 1979, s. 10, 35-37, 65-67.

25. Bjørn Svensson 1984, s. 14.

26. P. Eliassen $1926 / 80$, s. 26.

27. Søren Alkærsig 1901-03, s. 542.

28. Kancelliets brevboger $25 / 31579$.

29. "Jylland" ca. 1850. 1:480.000. Druck u. C. Flemming Glogau. Det Kongelige Bibliotek. Kortog Billedafdelingen. Foto nr. 188159.

30. "Hærvejen. Rapport $2 \lll 1982$. s. 13.

31. Alex Wittendorff 1973, s. 58.

32. P.V. Glob 1934, s. 233f; Salomon Frifelt 1934, s. 9f.

33. Ringkøbing amtskommune 1989 , s. 8.

34. Måske skulle man helt droppe ordet vej for at undgå associationer og nøjes med »korridor«.

35. Mogens Schou Jorgensen i: Mortensen, Peder \& Birgit M. Rasmussen 1988, s. 105.

36. Kr. Kålund 1913, s. 54f.

37. Adam af Bremen 1930, s. 242.

38. Steen B. Böcher 1966, s. 156f, J. Chr. Frederiksen 1923-27, Salomon Frifelt 1934, s. 197f; Marius Kristensen 1919-20, Jesper Madsen 1908, s. 39f; H. Thomsen 1924-25.

39. Johannes Møllgaard 1988, s. 61-99. Det følgende refererer til denne artikel.

40. I. Wallerstein: "The Modern World-System«. New York \& London 1974.

41. Johannes Mollgaard 1988, s. 94. 


\section{LITTERATUR}

Alkarsig, Seren: "Om dansk studehandel i det 18. århundrede«, i: Samlinger til Jysk historie og topografi 3. R, bd. III, s. 527-543.

Becker-Christensen, Henrik: Hærvejen i Sønderjylland et vejhistorisk studie. "Fra Kongeåen til Danevirke«, Åbenrå 1981.

Adam af Bremen: "De hamburgske ærkebispers historie«, Kbh. 1930

Böcher, Steen B.: "Træk af vejudviklingen i Danmark belyst gennem beliggenheden af vadesteder og broer «, i: Geografisk Tidsskrift bd. 65, 1966, s. 129-176.

la Cour, Vilhelm: Anm. Hugo Matthiessen: "Harvejen « i: Historisk Tidsskrift 10 R, 1 bd. 1930-31. Eliassen, P.: "Kongeåen eller Den gamle Granse“ 1926/80.

Frederiksen, J. Chr.: "Den gamle Drivervej«, i: Fra Ribe Amt 1923-27, s. 303-318.

Frifelt, Salomon J.: "Ad jyske Veje Sønderud«, 1934/59.

Glob, P.V.: "Den gamle Hærvej«, i: De danske heder bd. 1, 1963, s. 233-245.

Gregersen, H. V.: "Oldtidens og tidlig middelalders Hærvej uden om Urnehoved» i: SJy MSkr 1979, s. $439-444$.

Gregersen, H.V.: "En nyopdaget vejspærring ved Savsevejen « i: SJy MSkr 1976, s. 8-15.

„Harvejen pà cykel. Viborg Det store Vandskelı 1989. (1989a).

"Harvejen pd cykel. Oster Nykirke - Kongeåen 1989. (1989b).

"Harvejen på cykel. Jels Padborg" 1989. (1989c).

"Harvejen. Rapport nr. I", Harvejsgruppen 1976.

"Harvejen. Rapport nr. 2«, Fredningsstyrelsen 1982.

Kristensen, Marius: "Grænser og grænseveje« i: Fra Ribe Amt 1919-20, s. 279-288.

$K r$. Kdlund: »En islandsk vejviser for pilgrimme fra 12. århundrede« i: Aarbøger for nordisk oldkyndighed og historie 3R. bd. 3, 1913.

Lauritzen, Aage: "Nogle Hærvejsforgreninger ved Jelling« i: Vejle Amts Arbøger 1945, s. 5-55.

Lidegaard, Mads: "Hærvejen i Viborg amt «, Kbh. 1975.

Lidegaard, Mads: "Hærvejen langs Gudenåen«, Kbh. 1976.

Lidegaard, Mads: "Hærvejen i Vejle amt«, Kbh. 1977.

Lidegaard, Mads: "Hærvejen over Kongeåen«, Kbh. 1979.

Lidegaard, Mads: »Hærvejen mod grænsen«, Kbh. 1980.

Lidegaard, Mads: "Harvejen i Himmerland«, Kbh. 1983.

Linde-Laursen, Anders: »Hugo Matthiessens kulturhistorie 1989.

Madsen, Jesper: "Studehandelens historie i Danmark «, Arhus 1908.

Matthiessen, Hugo: "Torv og Harstræde«, Kbh. 1922.

Matthiessen, Hugo: »Hærvejen gennem Jylland. Introduktion til det jyske vejnets historie«, i: Festskrift til Kristian Erslev 1927, s. 107-130.

Matthiessen, Hugo: »Hvornhøj stenvaes. Det brolagte stykke af Hærvejen over Urnehoved", i: SJy MSkr 1929-30, s. 134-138.

Matthiessen, Hugo: »Hærvejen«, Kbh. 1930.

Matthiessen, Hugo: »Hærvejen« med efterskrift af Peter Seeberg 3. udg. 1981.

Mortensen, Peder \& Birgit M. Rasmussen (red): "Fra Stamme til Stat i Danmark 1. Jernalderens stammesamfund «, Jysk Arkæologisk Selskabs Skrifter XXII, 1988.

Mollgaard, Johannes: "Det 'mørke' Jylland og 'verdensmarkedet'«, i: Folk og kultur 1988, s. 61-99.

Ringkobing Amtskommune: »Oldtidsvejen« 1989.

Svensson, Bjorn: "Den delte Hærvej«, i: SJy MSkr 1967, (1967a) s. 145-165.

Svensson, Bjorn: »Rechte herr weg«, i: SJy MSkr 1967, (1967b) s. 209-219.

Svensson, Bjorn: »Oksevejen Haderslev - Immervad « i: SJy MSkr 1968, s. 5-14.

Svensson, Bjørn: "Fra Hærvej til motorvej«, Vojens 1984.

Sonderjyllands Amtskommune: "Stiplan for Hærvejen i Sønderjyllands amt«, 1984.

Thomsen, $H$.: "Studevejene, de gamle Drivveje paa Hertugdømmernes Grund før 1864«, i: SJy MSkr 1924-25, s. $110-111$. 
Vejle Amtskommune: „Fredningsplan«, Vejle 1985.

Vejle Amtskommune: "Notat om rekreative stiruter«, Vejle 1985.

Vejle Amtskommune: "Cykel- og vandretur ad Hærvejen i Vejle Amt«, Vejle 1986.

Vejle Amtskommune: "Forslag til Regionplan 1989«, Vejle 1989.

Viborg Amtskommune: »Hærvejen i Viborg Amt, rapport nr. 2« 1978.

Willerslev, Rich.: "Dansk Studehandel fra 1560 til 1660« i: Jyske Samlinger Ny R. 2 bd. 1952-54, s. 153-181.

Wittendorff, Alex: "Kongevej og alvej. Studier i samfærdselsforhold og vejenes topografi i det 16. og 17. århundrede«, Kbh. 1973.

Wittendorff, Alex: "Anm. af Mads Lidegaards harvejsbøger« i: Fortid og Nutid bd. 28., 1979-80, s. 164-165.

Arhus Amtskommune: "Stiplan for Harvejen i Århus Amt« 1982.

Kort 1. 